\title{
Development of the dominant follicle: mechanisms of selection and maintenance of oocyte quality
}

\author{
R Webb ${ }^{1}$ and BK Campbell ${ }^{2}$ \\ 'Division of Agricultural and Environmental Sciences, School of Biosciences, University of \\ Nottingham, Loughborough, Leicestershire, LE12 5RD, UK, ${ }^{2}$ Department of Obstetrics and \\ Gynaecology, School of Human Development, Queens Medical Centre, University of Nottingham, \\ Nottingham, NG7 $2 \mathrm{UH}, \mathrm{UK}$
}

For a follicle to reach dominance, in mono-ovulatory species such as cattle, requires the integration of a number of processes involving both extra-ovarian signals and intra-follicular paracrine and autocrine regulators. Ovarian transplant studies in both cattle and sheep demonstrated that it takes approximately 4 months for primordial follicles to reach dominance. Gonadotrophins are not a prerequisite for the continued growth of pre-antral follicles, unlike antral follicles, but FSH does appear to stimulate development. Local growth factors, such as IGFs and BMPs, are expressed throughout follicle development and interact with gonadotrophins to stimulate development. As follicles become dominant, there is a transfer of dependency from $\mathrm{FSH}$ to $\mathrm{LH}$. There are also differences in $\mathrm{LH}$ responsiveness of theca and granulosa cells during follicular development, due to differential regulation and control by intricate local mechanisms altering LH receptor (LHR) mRNA expression. In addition, both the BMP and IGF systems can modulate the proliferative and differentiative responses of both granulosa and theca cells to gonadotrophins. There is a significant interaction between BMPs and the IGF system in regulating follicular development. A range of factors, including nutrition, will also determine the fate of the growing follicle and the quality of the oocyte. Nearly all follicles regress and apoptotic cell death throughout follicular development is an underlying mechanism of cell loss during follicular atresia. Several markers of follicular atresia have been identified including IGFBPs. There is a significant correlation between the presence of low molecular weight IGFBPs in bovine follicular fluid and caspase- 3 activity of granulosa cells in individual follicles. In conclusion, it is the interaction between extra-ovarian and intra-ovarian factors that determine the fate of the follicle and the quality of the oocyte.

\section{Introduction}

Ovarian folliculogenesis is a lengthy and intricately regulated process marked by dramatic proliferation and precisely orchestrated differentiation of both the somatic and germ cell elements. Primordial follicles represent the source from which follicles will be recruited for growth throughout life, with paired ovaries of an individual containing around 100,000-250,000 of these follicles 
at birth (human: Gougeon 1996; sheep: Turnbull et al. 1977). Once follicles have been initiated to grow, the granulosa cells proliferate to form multilaminar structures (pre-antral follicles) which subsequently form a fluid filled space (antrum) and a well differentiated theca layer. Follicular development in sheep and cattle takes around 4-5 months with the majority of this time (3-4 months) being spent in the pre-antral stages of development (Cahill 1981; Gougeon 1996; Turnbull et al. 1977). When the follicle reaches a diameter of $200-400 \mu \mathrm{m}$, the antrum develops (Turnbull et al. 1977) and this is followed by widespread atresia (50-70\% for follicles over $1 \mathrm{~mm})$ so that the vast majority $(>99 \%)$ of follicles fail to ovulate.

It is widely accepted that control of the terminal stages of folliculogenesis lies primarily with the pituitary gonadotrophins, $\mathrm{FSH}$ and $\mathrm{LH}$, combined with the differential expression of somatic cell-derived growth factors that modulate the action of gonadotrophins at key points during the process of follicle development (Campbell et al. 1995; Webb et al. 1999). Communication between the oocyte and the surrounding somatic cells (Carabatsos et al. 2000), via a range of locally produced growth factors, is essential for the coordinated development of both cell types (Eppig 2001), making folliculogenesis a highly synchronised process. These local growth factor systems include the insulin-like growth factor (IGF) system (Webb et al. 1999), the inhibin/activin system (Knight \& Glister 2001) and the bone morphogenetic (BMP) system (Shimasaki et al. 2003; Knight \& Glister, 2006). In addition, recent studies also suggest that the oocyte, rather than being purely a passenger within the follicle, secretes numerous factors that modulate follicle development and ovarian function. Known oocyte-secreted factors include growth differentiation factor-9 (GDF-9) (Dong et al. 1996) and BMP-15 (Aaltonen et al. 1999; Dube et al. 1998) as well as factors in the germline alpha (FIG- $\alpha$ ) (Huntriss et al. 2002; Soyal et al. 2000) and c-kit receptor (Driancourt et al, 2000; Reynaud et al. 2000; Reynaud et al. 2001; McNatty et al. 2007 this supplement). However the temporal pattern and quantity of secretion of these factors has yet to be determined.

Ovarian follicular growth is therefore a developmental process during which the follicle progressively acquires a number of properties at a specific time and sequence, each of which is an essential prerequisite for further development. The orderly expression of these somatic and oocyte-derived factors, or "intrafollicular cascade", is thought to be essential for the development of the follicle to an ovulatory size, the subsequent production of an ovulatory signal and the release of a fully developmentally competent oocyte in response to that signal. Although some components of this intrafollicular cascade have been elucidated, most have been studied in isolation and the relative importance and temporal relationships between known and novel regulatory factors at different stages of follicle development remain to be elucidated. In this review we will examine recent advances in this area with respect to follicle development in sheep and cattle, concentrating primarily on the factors regulating antral and dominant follicle development.

\section{Pre-antral follicle development}

\section{Intra-ovarian factors}

Mechanisms regulating the activation and subsequent growth of primordial follicles have been reviewed in detail, particularly in relation to sheep (McNatty et al. 2007 this supplement) and so will not be reviewed here. In a number of species, as well as for the initiation of primordial follicle growth, the continued growth of pre-antral follicles is dependent upon the secretion of a range of local factors including GDF-9, BMPs, activins, inhibins, basic fibroblast growth factor (bFGF) and epidermal growth factor (EGF) (Knight \& Glister 2001; Smitz \& Cortvindt 2002; Webb et al. 2003; Hunter et al. 2004). As will be discussed, only studies identifying genetic mutations in sheep have been carried out (see Hanrahan et al. 2004; McNatty et al. 2007). However, Armstrong et al. (2002a) demonstrated that bovine pre-antral follicles express mRNAs encoding both IGFBP-2, -3 and type 1 IGF receptor. EGF, also stimulates pre-antral follicle growth (Gutierrez et al. 2000; Saha et al. 2000), 
Studies in our laboratory have also examined fetal ovaries for evidence of local regulatory systems operating during oogenesis. BMP- 6 and BMP receptors (BMPR) IA, IB and II have been shown to be present in bovine fetal ovaries between 2-9 months of gestation (Dugan et al. 2004; Fouladi-Nashta et al. 2005). The presence of both the ligand (BMP-6) and the receptors at this early stage illustrates the presence of a fully functional BMP system early in development. The expression of BMP-6 appears to be localised both in the oocyte, with the intensity of staining increasing with fetal age, and also in granulosa cells from 6 months of gestation. These results, together with results from post-natal bovine and ovine ovaries (Dugan et al. 2004), suggest that expression of both the ligand and the receptors is present right through gestation, parturition and into adulthood, since BMP-6 has been shown to be abundant in both the oocyte and granulosa cells of adult bovine follicles (Glister et al. 2004; Campbell et al. 2006). However, BMP-6, but not -2, -4 or -7 mRNA expression has been detected in ovine oocytes of pre-antral follicles (Juengel et al. 2006). Interestingly, Fatahei et al. (2005) was only able to immunolocalise BMP-2 and BMP-4 in bovine oocytes and theca cells of adult antral follicles, whereas BMPRII was observed in oocytes from the primordial stage. The functional significance of the expression patterns of components of the BMPs in domestic ruminants is unknown, but in the absence of knock-out models in this species, some inferences may be drawn from naturally occurring mutations.

McNatty et al. (2007) has reviewed the effect of null mutations of the oocyte secreted factors GDF-9 and BMP-15 in sheep. These studies show that these factors are essential for normal preantral follicle development. In contrast, the FecB mutation in the BMPRIB receptor, whilst inducing precocious maturation of ovulatory follicles (see later), has not been shown to have had a major effect on pre-antral follicle development, although some changes suggesting precocious develop-

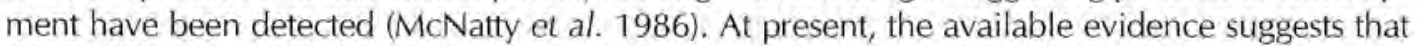
the FecB mutation results in a down-regulation in BMP signalling (Fabre et al. 2003) and therefore it appears likely that signalling through this receptor system is not of major importance during preantral follicle development, although it is possible that significant redundancy exists. The abundant expression of the BMPRIA receptor tends to support this possibility.

Research into the functional role of local regulatory systems during early folliculogenesis in ruminants and other mono-ovulatory species is severely hampered by the lack of physiological culture systems that will allow normal follicle and oocyte development from the primordial/primary stages of development through to antrum formation with high efficiency. Although significant advances have been made over recent years in this regard (Gutierrez et al. 2000; Fortune et al. 2000; McCaffery et al. 2000, Picton et al. 2003), existing systems remain sub-optimal and it is a research priority to develop in vitro model systems for these species.

\section{Extra-ovarian factors}

It is generally agreed that gonadotrophins are not involved in the initiation of follicle growth from the primordial follicle pool. FSH receptor (FSHr) mRNA is detected in follicles with only one or two layers of granulosa cells (Bao \& Garverick 1998) and both in vivo (Campbell et al. 2000) and in vitro (Gutierrez et al. 2000) studies have demonstrated that FSH can accelerate the rate of preantral follicle development. Expression of $\mathrm{LH}$ receptor $(\mathrm{LHr}) \mathrm{mRNA}$ is first detected when the theca interna forms around the granulosa cells (Bao \& Garverick 1998), presumably stimulating androgen precursor production. This is supported by a range of steroidogenic enzymes, these include cytochrome P450 side chain cleavage (P450scc), cytochrome P450 170-hydroxylase (P450c17), and 3ß-hydroxysteroid dehydrogenase (3B-HSD) mRNAs which are first expressed soon after formation of the theca interna (Bao \& Garverick 1998), with cytochrome P450 aromatase (P450arom) being localised solely to granulosa cells. Steriod enzyme protein information is very limited, although mRNA expression patterns agree with recent results showing that both small (KJ 
Dugan, M Lopez-Bejar, DG Armstrong and R Webb, unpublished observations) and larger (Thomas et al. 2001) pre-antral follicles are capable of producing oestradiol early in development.

Additional functional investigation into the role of gonadotrophins and their interaction with other extra-ovarian factors in vivo have utilised ovarian autografts treated with bovine somatotrophin (BST). In this model system, early follicle development is synchronised through the loss of growing follicles during graft re-vascularisation. In addition these studies in both sheep and cattle, in which gonadotrophin and insulin/IGF concentrations were modulated, showed that BST had a marked effect on the growing follicle population and that there was a clear interaction with gonadotrophic status (Campbell BK, Armstrong DG, Telfer EE and Webb R, unpublished observations). Thus, under normogonadotrophic conditions in hemi-ovariectomised sheep (FSH: $1.1 \pm 0.1 \mathrm{ng} / \mathrm{ml}$ ), BST treatment had a negative effect on the relative proportion of secondary/tertiary, pre-antral and antral follicles, whereas under hypergonadotrophic conditions (ovariectomised; FSH: $5.3 \pm 0.6 \mathrm{ng}$ / $\mathrm{ml}$ ) there were less secondary and tertiary follicles, but more late pre-antral and antral follicles in BST-treated animals (Campbell BK, Armstrong D \& Telfer E, unpublished observations). Whilst confirming our previous data (Campbell et al. 2000) that gonadotrophin levels influence the rate of pre-antral follicle development, these findings also support the hypothesis that the IGF system represents a key determinant of successful follicle and oocyte development during stages of preantral follicle development. Our current view is that exposure of the developing follicle and oocyte to the potent proliferative and differentiative actions of the IGFs is modulated through the abundant local expression of IGF-BP2 during the pre-antral stages of development (Webb et al. $2003 ; 2004$ ) and findings from follicle culture studies support this hypothesis (Walters et al. 2006). These findings therefore demonstrate possible interactions between extra-ovarian hormones and intra-ovarian growth factors in the control of these early stages of follicle development.

\section{Antral follicle development}

\section{Extra-ovarian factors}

The formation of a fluid filled cavity or antrum occurs at a diameter of $\sim 200-400 \mu \mathrm{m}$ in sheep and cattle (Turnbull et al, 1977). In hypophysectomised sheep antral follicle development continues to a diameter of $2-4 \mathrm{~mm}$. This stage of follicle development is commonly referred to as the gonadotrophin-responsive phase in recognition of the fact that while FSH can accelerate the rate at which these follicles grow, the presence of FSH is not an essential requirement (Webb et al. 1999), certainly for sheep. In contrast, antral follicle growth from 2-4 mm in diameter is under gonadotrophic control (Campbell et al. 1995), with each wave of follicular growth being preceded by a transient increase in FSH secretion (Adams 1999; Souza et al. 1997). The antral follicle stage marks the transition point from a proliferative to a differentiative phenotype for the follicular somatic cells and is accompanied by a decrease in mitotic index, a marked increase in the rate of follicular atresia (Turnbull et al. 1977) and marked changes in gene expression (Webb et al. 2003). Changes in the expression patterns of mRNAs for both gonadotrophin receptors (FSHr and $\mathrm{LHr}$ ) and steroidogenic enzymes, including P450scc, P450c17 and P450arom, and 3B-HSD (Bao et al. 1997; Webb et al. 1999) occur at this stage of development. An increase in follicular diameter to around $\sim 5 \mathrm{~mm}$ in diameter is characterized by induction of mRNA expression for P450scc and P450arom in granulosa cells. As follicles grow further there is increased expression of mRNA for P450scc and P450arom in granulosa cells and P450c17 in theca cells.

FSH infusion in cattle, in which pituitary gonadotrophin secretion had been significantly reduced by $\mathrm{GnRH}$ agonist ( $\mathrm{GnRHa}$ ) or $\mathrm{GnRH}$ immunisation, has been shown to stimulate follicle growth up to $8.5 \mathrm{~mm}$ in diameter (Crowe et al. 2001; Garverick et al. 2002). Also infusion of FSH in cattle can induce an increase in mRNA expression for P450scc and P450arom in granulosa cells 
in small (1-4mm) follicles (Garverick et al. 2002). Interestingly, although there is a seven-fold variation between cattle in the maximal number of follicles $>3 \mathrm{~mm}$ in diameter during follicular waves, there appears to be high repeatability of numbers of follicles $>3 \mathrm{~mm}$ in diameter during follicular waves within individual dairy cattle (Burns et al. 2005). This supports further the presence of a tightly regulated compensatory mechanism that regulates follicle growth as well as ovulation rate in sheep and cattle.

The development of methods to detect and increase the number of the gonadotrophin-responsive and gonadotrophin-dependent antral follicles is of immense practical significance for the application of assisted reproduction technologies in domestic species and in humans. The number and health of the antral follicle population represents the so-called "ovarian reserve" of antral follicles that will respond to ovarian stimulation protocols employing exogenous gonadotrophins (Macklon \& Fauser 2005), Conceptually, all ovarian stimulation protocols work on the principle of artificially increasing circulating FSH concentrations for a protracted period of time by administering gonadotrophin preparations that contain varying concentrations of FSH and $\mathrm{LH}$. This treatment recruits and stimulates a variable proportion of the gonadotrophin-responsive follicles present in the ovaries to an ovulatory stage. The oocytes within these follicles can be retrieved by ultra-sound guided ovum pick-up (OPU) prior to ovulation or flushed from the oviducts following ovulation. An exogenous ovulatory stimulus such as hCG (in humans) or GnRH (in cattle) is usually delivered to induce the final maturational changes in the follicles and oocytes prior to OPU. Irrespective of species, aggressive and unphysiological ovarian stimulation regimes produce oocytes of variable developmental competence (Kanitz et al. 2002; Macklon et al. 2006). In human ART, indicators of ovarian reserve such as FSH concentrations, antral follicle counts, inhibin B and anti-mullerian hormone $(A M H)$ concentrations are used increasingly to try and predict ovarian response to treatment and design suitable ovarian stimulation regimes (Macklon \& Fauser 2005; Visser et al. 2006; Yong et al, 2003). In domestic ruminants, whilst such individual treatment is impractical, there have been an increasing number of reports in the literature of the use of GnRH-analogues to enhance the response to ovarian stimulation (Berlinguer et al. 2006; Gonzalez-Bulnes et al. 2004; Lopez-Alonso et al. 2005). These enhanced responses seem to occur due to an accumulation in the number of follicles at the gonadotrophin-responsive to gonadotrophin-dependent threshold in animals rendered hypogonadotrophic by $\mathrm{GnRH}$-analogue treatment. However, whilst oocyte or embryo number may be enhanced by such GnRH-analogue treatment, some authors have reported poor embryo quality with these types of stimulation regimes (Berlinguer et al. 2006; GonzalezAnover et al. 2004; Lopez-Alonso et al. 2005). It is not known whether these effects on embryo quality reflect high rates of atresia in this pool of arrested gonadotrophin-responsive follicles or inadequacies in the gonadotrophin-stimulation regimes in these studies.

The development of follicles does not depend solely on gonadotrophins, but also the interaction with a range of local and circulating growth factors. For example, we have previously reported that treatment with BST, through increasing circulating insulin and IGF concentrations, can increase both the number of gonadotrophin-responsive follicles and their quality (Gong et al. 1991; 1993; 1997) and that embryo yield can be enhanced by stimulation of these follicles to the ovulatory stage using exogenous BST prior to FSH treatment (Gong et al. 2002).

\section{Intra-ovarian factors}

Utilising in vitro culture systems, a wide range of local factors, including members of the TGFB superfamily, FGFs and EGF/TGF $\alpha$ have been shown to be involved in the regulation of early antral follicle growth (Webb et al. 2003; 2004; Buratini et al. 2005). For example, BMP localisation studies have been carried out in adult sheep (Souza et al. 2002) and cattle (Glister et al. 2004). In 
line with rodent species (Shimasaki et al. 2004), and as discussed previously, there appears to be a functional BMP system within the ovary, with several BMPs being implicated as paracrine/ autocrine regulators of ovarian follicle development. In cattle, BMP-4 and -7 have been immunolocalised to theca cells and BMP- 6 has been immunolocalised to oocytes and granulosa cells (Glister et al. 2004) and BMPRIB and II to granulosa cells, theca cells and denuded oocytes from bovine antral follicles (Glister et al. 2004; Fatahei et al. 2005). As discussed for pre-antral follicles, in sheep, BMPRIA, IB and II receptors have been localised to the granulosa and theca cells of growing follicles (Souza et al. 2002) and BMP-6 is strongly expressed in the oocyte and granulosa cells, with weak expression in the theca cell layer of antral follicles (Campbell et al. 2006). The action of BMPs also appear to be modulated by a range of binding proteins e.g. follistatins; (see Lin et al. 2006; Knight \& Glister 2006), although more detailed study is required.

Functionally, BMP-2, -4 , and -6 have been shown to augment FSH-stimulate oestradiol and inhibin A production by cultured granulosa cells in sheep (Souza et al. 2002; Campbell et al. 2006). Similarly BMP $-4,-6$ and -7 have stimulated oestradiol, inhibin $-A$, activin $-A$ and follistatin, but without $\mathrm{FSH}$, in bovine granulosa cells (Glister et al. 2004). Conversely, BMPs in both cattle (BMP-4, -6 and -7: Glister et al. 2005) and sheep (BMP-2, -4 and -6: Campbell et al. 2006) are potent inhibitors of thecal androgen production. However, in sheep these BMPs have also been shown to stimulate thecal cell proliferation in vitro so that at very low doses total androgen production is actually increased by BMPs. Overall, these data suggest that BMPs are acting as both autocrine and paracrine factors to enhance ovarian steroidogenesis.

Recent studies utilising in situ hybridisation in sheep have confirmed that oocytes express mRNA for BMP-6, but failed to show mRNA expression for BMP-2, -4 and -7 in any cells of nonatretic ovarian follicles (Juengel et al. 2006). These data therefore suggest that BMP-6, like BMP15 and GDF-9, is an oocyte secreted factor that is the primary mediator of paracrine interactions with ovarian somatic cells. These results, however, conflict with those of Souza et al. (2002) who reported mRNA expression for BMP-2, $-4,-6$ and -7 in whole ovary from this species following Northern analysis. Further studies are therefore required in both sheep and cattle to confirm the tissue specific expression of potential ligands for the BMP receptors.

As an augmenter of somatic cell differentiation, the BMPs have a similar role to the IGF-system (Webb et al. 2003; 2004). Glister et al. (2004) demonstrated that BMP-4, -6 and -7 enhanced IGFinduced secretion of oestradiol, inhibin-A, activin-A and follistatin by bovine granulosa cells, but did not examine the interaction with the level of $\mathrm{FSH}$ stimulation. In contrast, recent data from sheep shows clearly that the BMPs are ineffective in stimulating granulosa cell differentiation in the absence of FSH, but do reveal a clear interaction between the level of IGF and BMP exposure in terms of the induction of aromatase activity (Campbell et al. 2006; Fig. 1). Thus, in this species both BMP and IGF act to augment FSH-stimulated cellular differentiation. Furthermore, bovine granulosa cell culture studies have recently suggested that FSH and oestradiol can down-regulate the expression of BMPRII (Jayawardana et al, 2006) and hence are possibly involved in the selection of bovine follicles. Moreover utilising ovarian tissue from ewes with the FecB mutation of BMPRIB showed that the mutation resulted in an increased response of both granulosa and theca cells to BMPs, gonadotrophins and IGF-I stimulation (Campbell et al. 2006). The increased responsiveness of ovarian somatic cells to these factors could account for the precocious maturation of antral follicles in FecB mutants, which is characterised by the development of aromatase activity and $\mathrm{LH}$ receptors by granulosa cells of antral follicles at markedly smaller diameters than in wildtype ewes (Driancourt et al. 1985; McNatty et al. 1985; 1987). These in vitro observations are therefore consistent with the profound effect of the FecB mutation in inducing precocious maturation of ovarian follicles (Webb et al. 1999; 2003) and hence deregulating the normal follicle selection mechanisms operating in this species. 
A

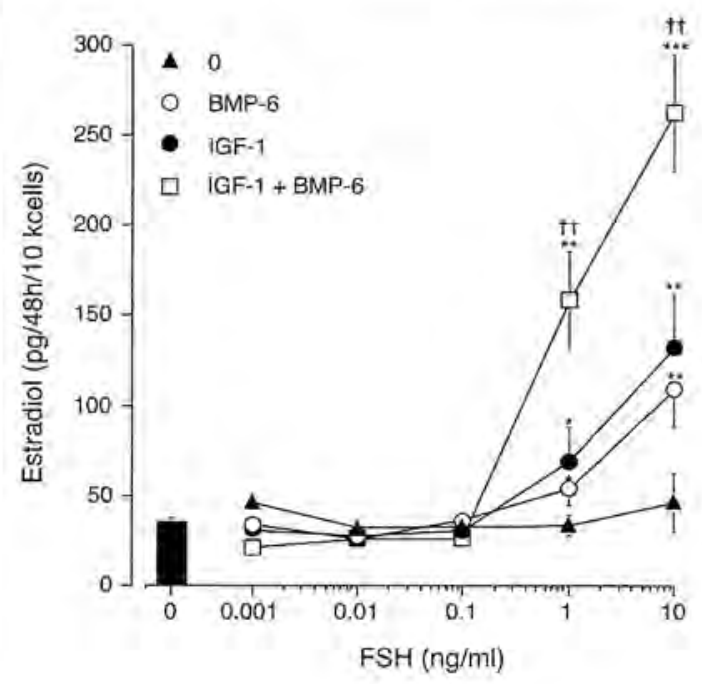

B

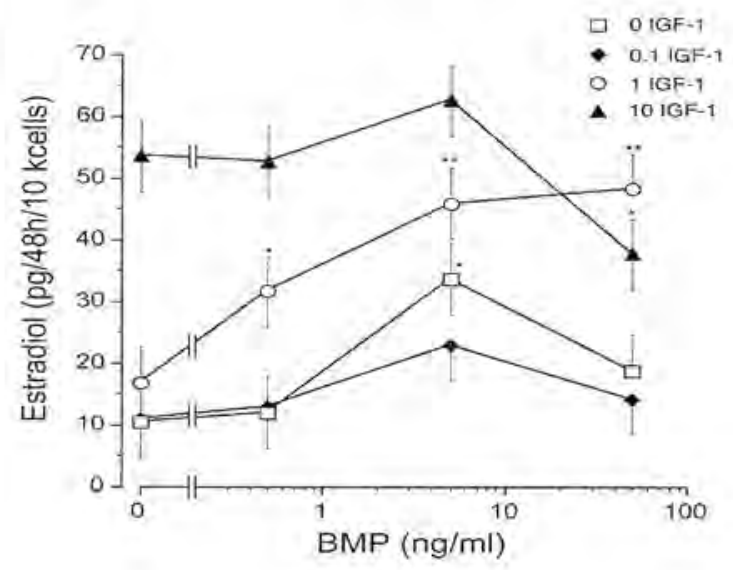

Fig. 1 A. Effect of increasing doses of oFSH in the presence of either $10 \mathrm{ng} / \mathrm{ml}$ insulin (full triangle), insulin and $5 \mathrm{ng} / \mathrm{ml} \mathrm{BMP-6}$ (open circle), insulin and $10 \mathrm{ng} / \mathrm{ml} \mathrm{IGF-1} \mathrm{LR3} \mathrm{(closed}$ circle) and insulin, BMP-6 and IGF-1 LR3 combined (open squares) on ovine granulosa cell in vitro oestradiol production. The column represents overall mean production in the presence of all factors, but in the absence of FSH. Asterix indicate significant difference from zero dose of FSH with $* \mathrm{P}<0.05$, **P<0.01 and $* * * P<0.001$. + indicates significant difference between BMP and IGF supplementation alone compared to the combined treatment at a given dose of FSH with BMP-6 and IGF-I LR3 $P<0.01$.

B. In vitro oestradiol production by ovine granulosa with increasing doses of BMP in the presence of $10 \mathrm{ng} / \mathrm{ml}$ insulin and FSH (open square), insulin, FSH and $0.1 \mathrm{ng} / \mathrm{ml} \mathrm{IGF-1} \mathrm{LR3}$ (full diamond), insulin, FSH and $1 \mathrm{ng} / \mathrm{ml}$ IGF- 1 LR3 (open circle) and insulin, FSH and 10 $\mathrm{ng} / \mathrm{ml} \mathrm{IGF-1} \mathrm{LR3} \mathrm{(closed} \mathrm{triangle).} \mathrm{Note} \mathrm{that} \mathrm{the} \mathrm{in} \mathrm{vitro} \mathrm{oestradiol} \mathrm{production} \mathrm{data} \mathrm{are}$ pooled from cultures utilising BMP-2, -4 and -6 due to similar responses to the three BMPs. A marked interaction between dose of BMP and IGF-1 is clearly evident from the data $(P<0.05)$, with a flattening of the BMP dose response curve with increasing dose of IGF-1. Asterix indicate significant difference from zero dose of BMP within each dose of LR3 IGF1 with $* \mathrm{P}<0.05,{ }^{* * P}<0.01$ and ${ }^{* * * P}<0.001$. After Campbell et al. 2006. 
As well as for the BMPs, the IGFs are also involved in local control mechanisms. It is around the time of antrum formation that IGF-II mRNA is first detected in thecal tissue in cattle. Type 1 IGF receptor and a range of IGFBPs (IGFBP-2, -3 and -4 ) have also been detected at this stage of development (Armstrong et al. 1998; 2000). Despite contradictory evidence on the production of IGF-1 by ovine and bovine granulosa cells (Webb et al. 2003; 2004), there is general agreement that IGF-II, produced by theca cells, is the major intrafollicular IGF ligand regulating the growth of bovine antral follicles (Yuan et al. 1998; Armstrong et al. 2000; Webb et al. 1999), acting through the type 1 IGF receptor (Lucy 2000), Despite the major site of IGF-II production being the thecal cells, Spicer et al. (2004) demonstrated that the stimulatory effects of IGF-II on thecal cell steroidogenesis, from large bovine follicles $(>7.9 \mathrm{~mm})$, is mediated via IGF type 1 receptors.

The ovarian IGF system also appears to interact directly with the oocyte. Small follicles from cattle offered high energy diets had significantly reduced expression levels of mRNA encoding IGFBP-2 and -4 (Armstrong et al. 2001), potentially regulating the bioavailability of IGF and hence influencing oocyte developmental potential. Concentrations of IGF-I that are optimal for follicle growth in vitro were seen to be detrimental to oocyte maturation (McCaffery et al. 2000). Hence, over-stimulation by IGFs, and possibly insulin, may be detrimental to oocyte quality (Armstrong et al. 2001). It appears that nutritionally induced changes in both circulating concentrations of insulin and IGF-I and the ovarian IGF system are important for follicle recruitment. However, these changes may also be detrimental to the quality of the oocyte within the growing follicle (Adamiak et al. 2005).

In conclusion, it is clear that the antral follicle stage is a transitional phase during which the follicle becomes increasingly dependent on the pituitary gonadotrophins as the rate of somatic cell proliferation declines and the cells differentiate and develop the ability to secrete increasing amounts of ovarian steroids and peptides. The control of this phase of development therefore involves complex interactions between local factors, many of which we now know are derived from the oocyte, other extra-ovarian factors circulating in the blood and the pituitary gonadotrophins. An outstanding characteristic of this follicle class is their heterogeneity and this reflects the fact that antral follicles each form their own micro-environment that will transduce gonadotrophic signals differentially. A positive response to a given level of gonadotrophic input will therefore ensure progression of a small number of individual follicles to the next large antral and/or dominant stage. The majority of follicles that reach this stage of development, however, will be unable to elicit a positive response to gonadotrophins and will be lost through the process of atresia.

\section{Dominant follicle}

\section{Extra-ovarian factors}

The precise mechanism for the selection of dominant follicles remains to be fully elucidated, but does involve the action of gonadotrophins as well as locally produced factors. As discussed, both $\mathrm{FSH}$ and $\mathrm{LH}$ exert their effects on follicular somatic cells via specific membrane bound receptors that exhibit alternate patterns of expression. It is well established that the granulosa cells of large oestrogenic (dominant) antral follicles in sheep and cattle develop LH receptors, (Webb \& England 1982; Ireland \& Roche 1982; Bao \& Garverick 1998; Webb et al. 1999; 2003) and it is now generally accepted that this event is critical to the process of follicle selection in mono-ovulatory species. It has been suggested that after the emergence of a follicular wave it is oestradiol and inhibin, produced by the growing and selected follicles that acts to suppress the secretion of FSH (Webb et al. 1999; 2003) resulting in the rapid deviation in the size of the future dominant follicle 
and the largest subordinate follicle (Kulick et al. 1999). Thus the presence of LH receptors (LHR) on granulosa cells is thought to allow a follicle to switch its gonadotrophic dependence from FSH to $\mathrm{LH}$ and attain dominance over a follicular cohort which remains FSH-dependent. Indeed Hampton et al. (2004) demonstrated that while FSH can support bovine follicular growth to $>10 \mathrm{~mm}$, LH increases androgen production and expression of $\mathrm{P} 450 \mathrm{c} 17$. Interestingly, changes in expression of mRNA for LHR in granulosa cells was not associated with changes in LH pulsatility and it was P450c17 mRNA expression, rather than aromatase activity, that was the most sensitive indicator of androgen production by thecal cells and oestrogen production by granulosa cells.

Study of the LHR in sheep and cattle has shown that LHR mRNA is highly polymorphic and a number of splice variants have been described. These isoforms vary due to deletion of all or part of two variable coding regions: one located between exon 3 and exon 7 and the other between exon 9 and exon 11, incorporating the first 266 bases of exon 11 (see Fig. 2A). To avoid confusion we have designated these $5^{\circ}$ and $3^{\circ}$ variable deletion sites (VDS) respectively. Several studies concentrating on the 3 VDS have described four mRNA isoforms, which are expressed in the ovary of large domestic ruminants and several other species and these have been designated 'A, B, F, and $\mathrm{G}^{\prime}$ isoforms in sheep, (Bacich et al. 1999), but appear to have corresponding isoforms in a number of other species including cattle, pig, rat and humans (Kawate \& Okuda 1998; Loosfelt et al. 1989; Reinholz et al. 2000). Full LHR functionality, which includes ligand specificity and nuclear signalling capacity, can only be conferred by the translation of the undeleted mRNA splice variant member of the 'A' form family. This form encodes an LH/hCG specific ectodomain (exons 1 to 10 ), and a membrane-bound nuclear signalling endodomain (exon 11); . Members of the ' $B$ ' and ' $G$ ' variant family mRNAs are truncated due to an early stop codon being included when part of exon 11 is spliced out resulting in an open reading frame shift. Putative proteins would therefore not incorporate any of the endodomain and would thus be soluble. The ' $F$ ' variant family loses exon 10 only and do not undergo frame shift. Therefore putative ' $F$ ' form LHR proteins should retain ligand specificity, and incorporate transmembrane and intracellular signalling regions. However to date no role has been suggested for either this soluble form or any of the putative proteins encoded by the various LHR mRNA isoforms and studies in our laboratory have shown no consistent change in the ratio between these isoforms during somatic cell differentiation in sheep either in vivo or in vitro (Marsters et al. 2007). This suggests that alternative splicing of the common precursor LHR primary RNA is regulated so as to produce a constant molar ratio between the mature transcripts. Thus the regulation of LHR expression in ovarian somatic cells requires further work to determine the biological role of the different splice variants,

To date several surveys of LHR mRNA in follicular somatic cells during the antral phase have been published, and provide valuable insights into the complexities of antral follicle development. The results of classic LH-binding (Carson et al. 1979; Webb and England 1982; Ireland \& Roche 1982; Peng et al. 1991) and in situ hybridisation studies (Xu et al. 1995), demonstrated that granulosa cells from large pre-ovulatory follicles have LH-binding capacity. Furthermore LHR mRNA expression has been detected by RT-PCR in both granulosa and theca cells throughout the antral phase of follicle development in sheep (Abdennebi et al. 2002) and cattle (Robert et al. 2003) and is markedly upregulated in granulosa cells from large, highly oestrogenic pre-ovulatory follicles (Bao et al. 1997). Moreover, recent findings suggest that post- transcriptional regulation of LHR may involve LHR mRNA-binding proteins (LRBPs) that induce rapid degradation (Kash \& Menon 1999). These workers have identified an LRBP binding site adjacent to the transcription start site and demonstrated that LRBP/LHR mRNA complexes are more rapidly degraded than unencumbered LHR mRNA thereby limiting time for translation. More work is therefore required to examine the mechanisms regulating the transcription and translation of LHR mRNA in the somatic cells of ovarian follicles in domestic ruminants. 
A
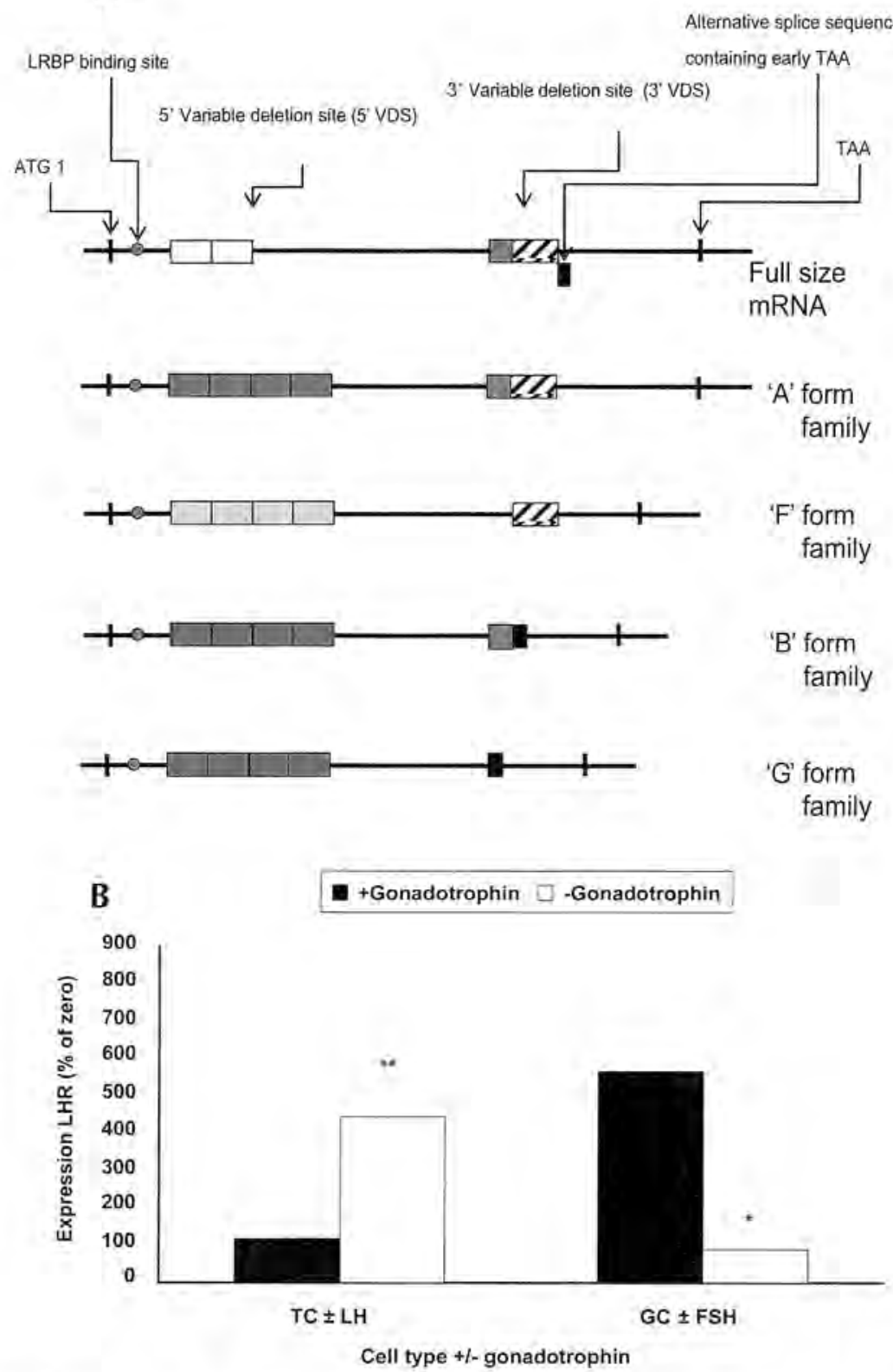

Fig. 2. A. Schematic representation of the $\mathrm{LH}$ receptor full size mRNA showing the positions of the $5^{\circ}$ and $3^{\circ}$ variable deletion sites (VDSs) and other important loci. Also shown the alternative splicing of the $3^{\circ}$ VDS which determines the variant families (A, F, B and G).

B. Semi-quantitative comparison of total LH receptor mRNA expression in theca cells (TC) and granulosa cells (GC) taken from small bovine antral follicles $(3-5 \mathrm{~mm})$ and cultured for $96 \mathrm{hrs}$ in serum-free media \pm gonadotrophins (LH and FSH respectively). Expression was determined by RT-PCR. Asterisks denote individual statistical significances ( $*, P<0.05$; **, $P<0.01$ ) between the \pm gonadotrophin treatments. After Marsters et al, 2007. 
Recent studies using somatic cells induced to differentiate in vitro have revealed important differences in the way that follicle stimulating hormone receptors (FSHR) and LHR expression are regulated. Granulosa cell FSHR expression appears to be constitutive from the primary stage of follicle development through to the dominant follicle. We have previously reported that FSHR expression in cultured granulosa cells declined rapidly in the period after plating and, in the presence of optimum doses of FSH and IGF-1, increase rapidly prior to induction of aromatase activity and gene expression (Marsters et al. 2003). Removal of FSH, but not IGF from culture media, however, results in a marked attenuation in this recovery in FSHR expression and the absence of aromatase indicating that FSH positively regulates expression of its own receptor in granulosa cells (Marsters et al. 2007). Further, expression of LHR in granulosa cells follows a similar pattern that parallels aromatase expression, confirming that induction of LHR in granulosa cells is an FSH dependent phenomenon that occurs concurrently with acquisition of the ability to secrete oestradiol. Conversely, LHR expression in cultured theca cells exhibits a similar profile, but is markedly up-regulated in the absence of LH in the media, indicating that thecal LHR expression is negatively regulated by LH in this species (Marsters et al. 2007; Fig. 2b).

At a more functional level, infusion studies in cattle have demonstrated that FSH alone, or in combination with $\mathrm{LH}$, can stimulate follicles to develop to the preovulatory stage and these preovulatory follicles are capable of ovulating in response to hCG (Webb et al. 2003). Furthermore, adequate pulsatile LH support appears to be required to maintain the ovulatory competence of large follicles ( $>9 \mathrm{~mm}$ in diameter) when FSH concentrations are decreased. These studies also indicated that gonadotrophins are significantly involved in the control of ovulation rate. This is supported by the finding that cattle with three dominant follicles had higher FSH concentrations than cattle with two dominant follicles, with cattle with a single dominant follicle having the lowest mean FSH concentration (Lopez et al. 2005). These data in cattle are comparable with those generated using a similar model in sheep and agree with our current understanding of the role of declining FSH and subsequent $\mathrm{LH}$ support in selection of the dominant follicle. The results of recent experiments utilising a GnRH-antagonist suppression model confirm that $\mathrm{LH}$ is an essential requirement for normal ovulatory follicle development and subsequent luteal function, but show that a pulsatile mode of $\mathrm{LH}$ stimulation is not required by the ovulatory follicle for normal dominant follicle development and luteal function (Campbell et al. 2007; Fig. 3). These data suggest therefore that as well as an FSH threshold being necessary for the support of gonadotrophin-dependent follicles, a threshold concentration of $\mathrm{LH}$ is required for normal steroidogenesis and development of the dominant follicle. In addition to these direct effects of $\mathrm{LH}$ on dominant follicle development, $\mathrm{LH}$, by modulating both oestradiol and inhibin A secretion by the ovulatory follicle, can also indirectly control the level of pituitary $\mathrm{FSH}$ release and hence the fate of $\mathrm{FSH}$-dependent follicles.

Dominant follicles, even in the first follicular wave of the oestrous cycle, are mature enough to ovulate and corpora lutea $(\mathrm{CL})$ can be generated experimentally by treatment with a number of factors including hCG (Price \& Webb 1989), GnRH (Mee et al. 1991; 1993) and GnRH analogues (Twagiramungu et al. 1995). However the CL appears to be impaired with reduced progesterone production (Webb et al. 1992). In addition to impaired CL function, Perry et al. (2005) demonstrated that administration of GnRH to induce ovulation likely initiates a preovulatory gonadotrophin surge before some dominant follicles attain physiological maturity. Also GnRH-induced ovulation of follicles that are physiologically immature had a negative impact on pregnancy rates and late embryonic/fetal survival. It was suggested (Perry et al. 2005) that these observations in cattle may have implications for human assisted reproductive procedures. However there appears to be an optimum duration of ovulatory follicle development since an 
increased duration from the time of emergence (or dominance) to oestrus is associated with reduced pregnancy rates following $\mathrm{Al}$ in dairy cows undergoing spontaneous oestrous cycles (Bleach et al. 2004).
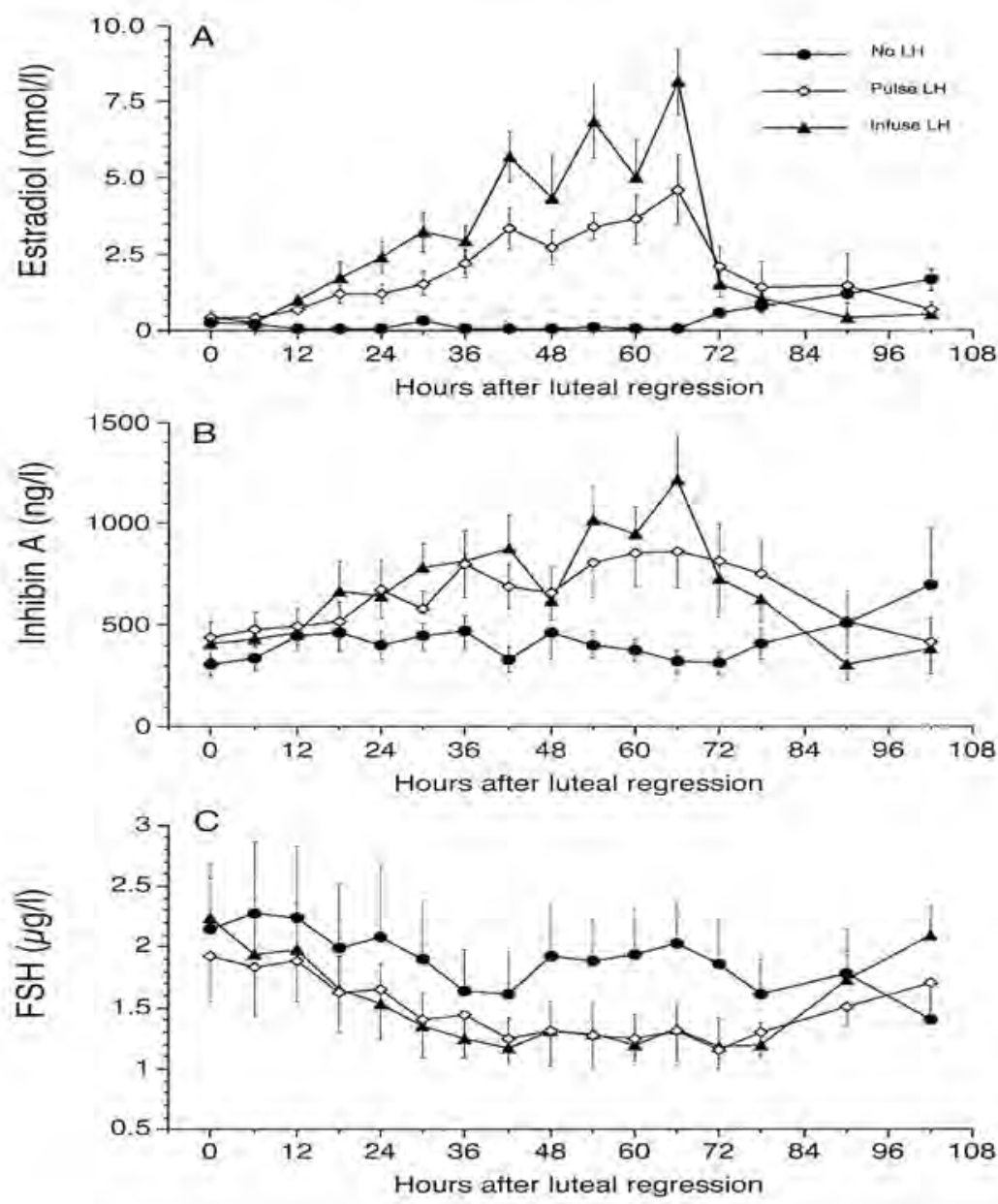

Fig. 3 Ovarian venous oestradiol (A) and inhibin A (B) and jugular venous FSH (C) concentrations in GnRH agonist suppressed ewes which received either no $\mathrm{LH}(\mathrm{n}=8$; closed circles), pulsed LH ( $n=8$; open diamonds) or constant LH ( $n=8$; closed triangles) for $60 \mathrm{~h}$ after induction of luteal regression followed by an ovulatory stimulus at that time. The results demonstrate a key $\mathrm{LH}$ requirement for final maturation. However, these results also demonstrate that both the oestradiol and inhibin A responses occurred whether LH was given as a constant infusion or as pulses. After Campbell et al. 2007.

Other extra-ovarian factors are also involved in dominant follicle function. A large number of in vitro studies have demonstrated the direct action of metabolic factors on granulosa and theca cells (Webb et al. 1999; 2003; 2004; Armstrong et al. 2003). Bovine granulosa cells also appear to be dependent on the presence of physiological concentrations of insulin (Gutierrez et al. 1997) and furthermore, infusion of insulin into beef heifers increased the diameter of the dominant follicle (Simpson et al. 1994). Dietary-induced increases in circulating concentrations of insulin have also been correlated with increased oestradiol production in cultured 
granulosa cells from small antral $(1-4 \mathrm{~mm})$ follicles (Armstrong et al. 2002b), demonstrating a direct action of metabolic hormones throughout the later stages of follicle development. This is supported by results of a study in post-partum dairy cows where insulin infusion increased oestradiol secretion after $30 \mathrm{~h}$ by the dominant follicle of the first postpartum follicular wave. Interestingly these changes appeared not to be mediated through changes in pulsatile $\mathrm{LH}$ release (Butler et al. 2004), suggesting a direct effect of insulin on the follicle. However circulating free IGF-1 was also raised, which as discussed, could have increased the response of the follicle to peripheral gonadotrophins resulting in increased aromatase activity by the dominant follicle. Hence there appears to be an optimum concentration of insulin for follicle health, since it has recently been demonstrated that hyperinsulinemia can occur in cattle and that this condition is associated with impaired oocyte quality (Adamiak et al. 2005; 2006). Interestingly in this study, there was an interaction between body condition and level of feeding, which were cumulative, with both a positive and negative influence on oocyte quality as measured by the ability of oocytes to develop to blastocysts, with high level of feeding having a beneficial effect in animals of low body condition, but a detrimental effect in cows with a moderately high body condition.

\section{Intra-ovarian factors}

As the selected follicle reaches dominance there are also changes in the expression patterns of locally produced factors. For example, in healthy bovine follicles up to $9 \mathrm{~mm}$ in diameter, IGFBP-2 and -4 mRNA expression are restricted to granulosa and theca tissue, respectively (Webb et al. 2003; 2004). Indeed the conversion of a subordinate follicle to a future dominant follicle has been associated with a transient increase in follicular fluid activin A and oestradiol, but a decrease in IGFBP-2 (Armstrong et al. 1998; Ginther et al. 2002; Kojima et al. 2003). The reduction in follicular fluid IGFBP-2 and -4 concentrations has been coupled to the increase in oestradiol concentrations, in dominant follicles in cattle (Mihm et al. 2000). Hence, lower amounts of IGFBP-2 and increased LH receptors in granulosa cells appear to be associated with the establishment of the dominant follicle (Webb et al. 2003; 2004).

This reduction in IGFBPs has been associated with increased proteolytic activity (Mazerbourg et al. 2000). The protease that degrades IGFBP-4 and -5 has been shown to be the pregnancyassociated plasma protein -A (PAPP-A) (Monget et al. 2003). PAPP-A mRNA expression is also more abundant in growing dominant bovine follicles than in non-selected small follicles (Fayad et al. 2004). Furthermore it has been shown that PAPP-A is responsible for IGF-dependent degradation of IGFBP-2 probably leading to increased IGF bioavailability (Monget et al. 2003). Post-translational modification of IGFBPs are also known to occur and it has been demonstrated that at least 51 isoforms of IGFBP are present in bovine follicular fluid (Nicholas et al. 2002), but the physiological role of these isoforms has yet to be clarified.

Other locally produced growth factors include members of TGFß superfamily of ligands, operating through Smad signalling pathways (Knight \& Glister 2006). Certainly a range of BMPS and associated factors are involved in follicular maturation as indicated by the marked increase in ovulation rate in sheep with a range of mutations (McNatty et al, 2007 this supplement). As with other stages of follicle development there is now evidence for a functional role of BMPs in the dominant follicle, acting in concert with other locally produced factors and gonadotrophins. However, the exact mechanisms through which all these growth factors operate and the degree of redundancy need to be elucidated.

In addition to known local factors, recent data derived from genetic array approaches (Mihm et al. 2006) have revealed a large number of factors that may be associated with dominance in 
mono-ovulatory species. Some of these effects, such as the association of dominance with the development of LH receptors on granulosa cells (Evans et al. 2004; Mihm et al. 2006) are well estäblished (Webb \& England 1982; Xu et al. 1995), whereas many others have unknown actions which may or may not be causally related to the attainment of dominance. Furthermore, other factors of unknown identity have been described through the more conventional means of the observation of a biological effect. One of the most intriguing of these activities, given the increased understanding of the importance of oocyte secreted factors in controlling follicular development, is the observation that oocytes from a number of species release a potent activity that is capable of inhibiting gonadotrophin-induced differentiation of granulosa cells in vitro without markedly affecting cellular proliferation (pig: Brankin et al. 2003; cow: Glister et al. 2003; sheep: Sfontouris 2004; Table 1). Comparison of the effect of culturing ruminant granulosa cells with a single oocyte on cell number and oestradiol production, with the known effects of candidate factors for this activity such as GDF-9, BMP-15, BMP-6 and TGFo/EGF (see Table 1), reveal that GDF-9/BMP-15 are possible candidates for this activity. This inhibitory action is consistent with the sheep models in which ovulation rates are increased in heterozygote carriers of null mutations (Hanrahan et al. 2004) and following immuno-neutralisation (Juengel et al. 2004). The role of GDF-9/BMP-15 in the control of dominance is therefore worthy of future investigation with a primary question being the mechanism whereby this putative inhibitory moiety is controlled during selection.

Table 1: Comparison of the eifects of co-culture of oocytes with granulosa cells from sheep and cattle on cellular proliferation and oestradiol production under optimal conditions for induction of cellular differentiation (i.e. in the presence of IGF-1 and FSH) with other known oocyte-secreted factors, After Glister et al. 2003; Campbell et al. 2005 .

\begin{tabular}{lccc}
\hline Factor & Proliferation & Oestradiol production & Reference \\
\hline Oocyte co-culture (+FSH/IGF) & None & Negative & $\begin{array}{l}\text { Glister et al. 2003 } \\
\text { Sfontouris 2004 }\end{array}$ \\
BMP-6 (+FSH/IGF) & None & Positive & Glister et al. 2004 \\
TGF $\alpha /$ EGF (+FSH/IGF) & Positive & Negative & Glister et al. 2003 \\
GDF-9/BMP-15 (+FSH/IGF) & None & Negative & Campbell et al. 1996 \\
\hline
\end{tabular}

\section{Follicular atresia}

As discussed, atresia occurs throughout follicular development and apoptotic cell death is an underlying mechanism of cell loss during follicular atresiá (Tilly et al. 1991). Granulosa cell apoptosis may occur early in the process of atresia in rodents, before other morphological or biochemical changes are detected (Tilly et al. 1992), although in cattle a decline in intrafollicular oestradiol production has been shown to precede apoptosis of granulosa cells (Austin et al. 2001). The theca interna is also susceptible to cell death, with a reduced number of P450SCC-positive cells in atretic follicles (Clarke et al. 2004). Indeed theses authors suggested that the theca interna could be a site of initiation of atresia.

Atresia, along with follicular growth differentiation and ovulation are dependant on cyclical remodelling of the extra cellular matrix (ECM). For example plasminogen activators and inhibitors, including protease nexin-1 ( $P N-1)$ have been associated with the process of atresia in non-ovulatory dominant bovine follicles (Cao et al. 2006). In addition, gelatinolytic and caseinolytic matrix metalloproteinase's (MMPs) which degrade the proteinaceous components of the ECM are temporally and spatially regulated within the thecal and granulosa compart- 
ments of bovine follicles (Smith et al. 2005). Indeed, gelatinase A (MMP-2) activity was increased in response to physiological concentrations of $\mathrm{LH}$. The controlled degradation of ECM proteins by MMPs and their inhibitors (TIMPs) may be essential for preserving a microenvironment conducive to follicular function.

A number of markers of atresia have been used to assess follicular status including caspases (Fenwick \& Hurst 2002), Fas and Fas-L (Quirk et al. 2000), TUNEL staining of granulosa cells (Zeuner et al. 2003) and IGFBP-5 expression (Devine et al. 2000). Whilst several of these markers have been used to identify atretic follicles, very little evidence of their subsequent use as markers of oocyte quality exists (Nicholas et al. 2005). Unlike progression of apoptosis in oocytes, that relies on caspase-2, apoptosis in granulosa cells from pre-antral to preovulatory follicles is dependent upon the activity of caspases -3 and -7 (Matikainen et al. 2001). In cattle, it has been demonstrated that follicular atresia is accompanied by a considerable increase in the lower molecular weight IGFBPs (Nicholas et al. 2005). Importantly, IGFBP-5 appears to be a particularly good marker of atresia, since other IGFBPs are expressed at different stages of follicular development, whereas IGFBP-5 is exclusive to atresia (Monget et al. 1998). Indeed, it has recently been demonstrated that the IGFBP expression profile of follicular fluid can be used to better predict oocyte developmental competence (Nicholas et al. 2005). A distinctive IGFBP profile in follicular fluid of ovarian follicles has been demonstrated, with the dominant bovine follicle containing only IGFBP-3 together with a high oestradiol content, whereas the two largest subordinate follicles contain increased levels of IGFBP-2, -4 and the 29-31kDa (IGFBP-5) band, concomitant with reduced oestradiol content (Fig. 4). Furthermore, an extremely significant correlation between $29-31 \mathrm{kDa}$, (IGFBP-5) expression in follicular fluid and caspase- 3 activity in the granulosa cells, measured in the same follicles, has been shown (Nicholas et al. 2005; Fig. 4), demonstrating that IGFBP expression patterns can be used to group follicles into healthy, early atretic and late atretic follicles. Furthermore, a higher proportion of oocytes derived from follicles in early atresia progressed to the blastocyst stage after IVF (Fig. 4).

Gross morphological assessment of cumulus oocyte complexes is not an accurate method of determining whether oocytes have been derived from healthy or atretic follicles (Nicholas et al. 2005). Hence, selecting oocytes from follicles of defined quality using non-invasive markers, for example, IGFBP expression patterns, which can be performed rapidly enough to preselect the oocytes prior to IVF would be a major advantage. Selection of good quality oocytes is also highly desirable for procedures that require extensive manipulations such as pronuclear microinjection, intra-cytoplasmic sperm injection (ICSI) and nuclear transplantation, which need to ensure a high developmental competence after embryo transfer. These results may enable an improvement in IVF pregnancy rates from the current success rate of $\sim 30 \%$ by pre-selection of oocytes on a more biochemically sound basis than by simple morphological evaluation, which is currently used, and is a rather non-empirical method of assessment.

\section{Conclusions}

The final stages of follicle development are driven by an absolute requirement for gonadotrophic support (see Fig. 5). In addition, this requirement is developmentally regulated with dominant follicles changing their reliance from FSH to $\mathrm{LH}$ support. The response of these follicles to gonadotrophins is modulated by other extra-ovarian factors, such as insulin and IGF-1, which also influence follicle development, oocyte quality and a panoply of locally produced growth factors. This review has centred on those that have been studied in most detail, namely the IGF and BMP systems. Limited, but rapidly increasing, information to date has already demonstrated an interaction between these two important local regulatory systems (see Fig. 5). Fur- 
A

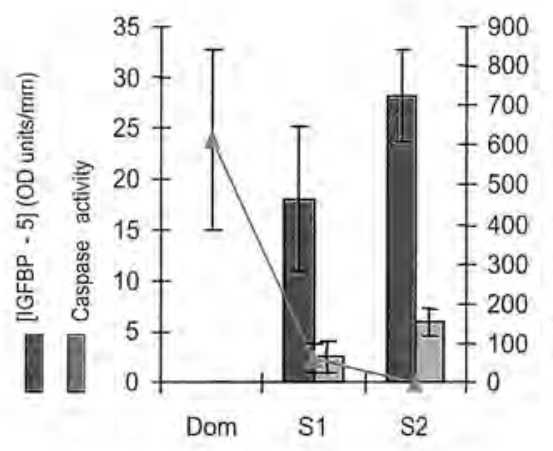

C

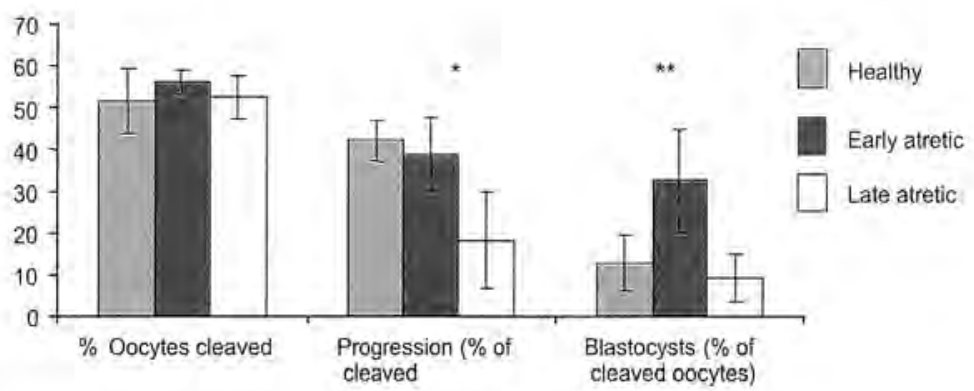

Fig. 4 Bovine granulosa cell caspase-3 activity, oestradiol $17 B$ follicular fluid IGFBP-S and concentrations (A), and (B) IGFBP content, visualised by Western ligand blot using biotinylated IGF-II, in follicular fluid from ovarian follicles from synchronised heifers on day 5 after oestrus and (C) the outcome of in-vitro fertilization on pre-selected oocytes from non-synchronised animals. Adapted from Nicholas et al. 2005.

thermore, gene expression profiling approaches will identify additional novel and differentially expressed genes within follicles. The challenge for the future, following identification of these factors, will be the determination of their physiological role, in particular how they interact with extra-ovarian factors. An increased understanding of these complex systems controlling follicular development will result in the in vivo and in vitro production of better quality oocytes resulting in enhanced embryo survival and pregnancy rates.

\section{Acknowledgements}

The authors would like to express their thanks to the funding agencies (BBSRC, Defra and SEERAD), who supported much of their cited work. 


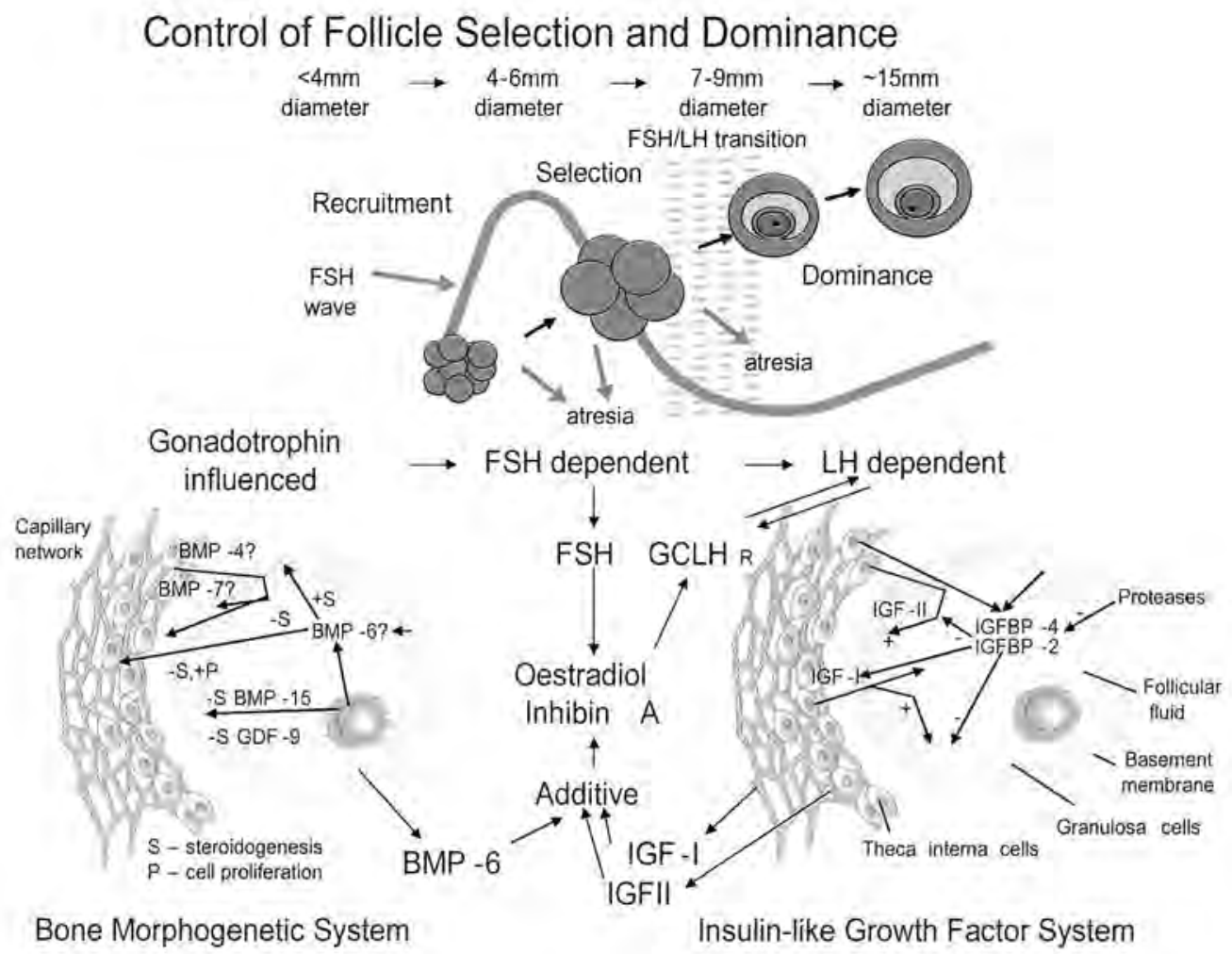

Fig. 5 Diagram showing the role of gonadotrophins in antral follicle development and the interaction with the follicular IGF and BMP systems. Note the additive effect of the IGF and BMP systems on FSH stimulated follicular development. Adapted from Webb et al. 2003; Campbell et al. 2006.

\section{References}

Aaltonen J, Laitinen MP, Vuojolainen K, Jaatinen $\mathrm{R}$, Horelli-Kuitunen N, Seppa L, Louhio H, Tuuri T, Sjoberg J, Butzon R, Hovatta O, Dale L \& Ritvos O 1999 Human growth differentiation factor 9 (GDF9) and its novel homolog GDF-9B are expressed in oocytes during early folliculogenesis. Journal Clinical Endocrinology and Metabolism 84 2744-2750.

Abdennebi L, Lesport AS, Remy JJ, Grebert D, Pisselet C, Monniaux D \& Salesse R 2002 Differences in splicing of mRNA encoding $\mathrm{LH}$ receptor in theca cells according to breeding season in ewes. Reproduction 123 819-826.

Adamiak SJ, Mackie K, Watt RG, Webb R \& Sinclair KD 2005 Impact of nutrition on oocyte quality: cumulative effects of body composition and diet leading to hyperinsulinemia in cattle. Biology of Reproduction 73 918-926.

Adamiak SI, Powell K, Rooke JA, Webb R \& Sinclair K
D 2006 Body composition, dietary carbohydrates and fatty acids determine post-fertilisation development of bovine oocytes in vitro. Reproduction 131 247-258.

Adams GP 1999 Comparative patterns of follicle development and selection in ruminants. Journal of Reproduction and Fertility Supplement $\mathbf{5 4}$ 17-32.

Armstrong DG, Baxter G, Gutierrez CG, Hogg CO, Glazyrin AL, Campbell BK, Bramley TA \& Webb R 1998 Insulin-like growth factor binding protein -2 and -4 mRNA expression in bovine ovarian follicles: effect of gonadotropins and developmental status. Endocrinology 139 2146-2154.

Armstrong DG, Gutierrez CG, Baxter G, Glazyrin AL, Mann GE, Woad KJ, Hogg CO \& Webb R 2000 Expression of mRNA encoding IGF-I, IGF-II and type 1 IGF receptor in bovine ovarian follicles. Journal of Endocrinology 165 101-113. 
Armstrong DG, McEvoy TG, Baxter G, Robinson J, Hogg CO, Woad KJ \& Webb R 2001 Effect of dietary energy and protein on bovine folliculat dynamics and embryo production in vitro: associations with the ovarian insulin-like growth factor system. Biology of Reproduction 64 1624-1632.

Armstrong DG, Baxter G, Hogg CO \& Woad KJ 2002a Insulin-like growth factor (IGF) system in the oocyte and somatic cells of bovine pre-antral follicles. Reproduction $123789-797$

Armstrong DG, Gong JG, Gardner JO, Baxter G, Hogg CO \& Webb R 2002b. Steroidogenesis in bovine granulosa cells: the effect of short-term changes in dietary intake. Reproduction 123 371-378.

Armstrong DG, Gong JG \&. Webb R 2003 Interactions between nutrition and ovarian activity in cattle: phystological, cellular and molecular mechanisms. Reproduction Supplement 61 403-414.

Austin EJ, Mihm M, Evans ACO, Knight PG, Ireland JLH, Ireland JI \& Roche JF 2001. Alterations in intrafollicular regulatory factors and apoptosis during selection of follicles in the first follicular wave of the bovine estrous cycle. Biology of Reproduction 64 839-848.

Bacich DJ, Earl CR, O'Keefe DS, Norman RJ \& Rodgers RJ 1999 Characterisation of the translated products of the alternatively spliced luteinising hormone receptor in the ovine ovary throughout the oestrous cycle. Molecular and Cellular Endocrinology 147 113-124.

Bao B \& Garverick HA 1998 Expression of steroidogenic enzyme and gonadotropin receptor genes in bovine follicles during ovarian follicular waves: a review. Jourmal of Animal Science 76 1903-1921.

Bao B, Garverick HA, Smith GW, Smith MF, Salfen BE \& Youngquist RS 1997 Changes in messenger ribonucleic acid encoding luteinising hormone receptor, cytochrome P450-side chain cleavage, and aromatase are associated with recruitment and selection of bovine ovarian follicles Biology of Reproduction 56 1158-1168.

Berlinguer F, Gonzalez-Bulnes A, Succu S, Leoni GG, Veiga-Lopez A, Mossa F, Garcia-Garcia RM, Debbere D, Galioto M, Cocero MJ \& Naitana S 2006 GnRH antagonist enhance follicular growth in FSH-treated sheep but affect developmental competence of oocytes collected by ovum pick-up. Theriogenology 65 1099-1109.

Bleach ECL, Glencross RG \& Knight PG 2004 Association between ovarian follicle development and pregnancy rates in dairy cows undergoing spontaneous oestrous cycles, Reproduction 127 621-629.

Brankin V, Mitchell MRP, Webb R \& Hunter MG 2003 Paracrine effects of oocyte secreted factors and stem cell factor on porcine granulosa and theca cells in vitro. Reproductive Biology and Endocrinology 155 $1-15$.

Buratini Jr J, Teixeira AB, Costa IB, Glapinski VF, Pinto MGL, Giometti IC, Barros CM, Cao M, Nicola ES \& Price CA 2005 Expression of fibroblast growth factor -8 and regulation of cognate receptors, fibroblast growthfactor receptor-3c and -4 in bovine antral follicles. Reproduction 130 343-350.

Burns DS, Jimenez-Krassel F, Ireland JLH, Knight PG \& Ireland JJ 2005 Numbers of antral follicles during follicular waves in cattlet evidence for high variation among animals, very high repeatability in individuals, and an inverse association with serum follicle-stimulating hormone concentrations. Biology of Reproduction 73 54-62.

Butler ST, Pelton SH \& Butler WR 2004 Insulin increases $17 ß$-estradiol production by the dominant follicle of the first postpartum follicle wave in dairy cows. Reproduction 127 537-545.

Cahill L 1981 Folliculogenesis in the sheep as influenced by breed, season and oestrous cycle. Journal of Reproduction and Fertility Supplement 30135 142.

Campbell BK, Scaramuzzi RJ \& Webb R 1995 Control of antral follicle development and selection in sheep and cattle. Journal of Reproduction and Fertility Supplement 49 335-350.

Campbell BK, Scaramuzzi RJ \& Webb R 1996 Induction and maintenance of oestradiol and immuno-reactive inhibin production with FSH by ovine granulosa cells cultured in serum free media. Journal of Reproduction and Fertility 106 7-16.

Campbell BK, Telfer EE, Webb R \& Baird DT 2000 Ovarian autografts in sheep as a model for studying folliculogenesis. Molecular and Cell Endocrinology 163 137-139.

Campbell BK, Sharma S, Shimasaki S \& Baird DT 2005 Effect of AMH, BMP-15 and GDF-9 on FSH-induced differentiation of sheep granulosa cells. Biology of Reproduction Special Issue Abstract 728.

Campbell BK, Souza CJH, Skinner AJ, Webb R \& Baird DT 2006 Enhanced response of granulosa and theca cells from sheep carriers of the FecB mutation in vitro to gonadotropins and bone morphogenetic protein-2, -4, and -6. Endocrinology 147 1608-1620.

Campbell BK, Kendail NR \& Baird DT 2007 The effect of the presence and pattern of LH stimulation on ovulatory follicle development in sheep. Brology of Reproduction (in press).

Cao M, Buratini Ir J, Lussier JG, Carrière PD \& Price CA 2006 Expression of protease nexin-1 and plasminogen activators during follicular growth and the perioyulatory period in cattle. Reproduction 131 125137.

Carabatsos MJ, Sellitto C, Goodenough DA \& Albertini DF 2000 Oocyte-granulosa cell heterologous gap junctions are required for the coordination of nuclear and cytoplasmic meiotic compefence. Developmental Biology 226 167-79.

Carson RS, Findlay IK, Burger HG \& Trounson AO 1979 Gonadotropin receptors of the ovine ovarian follicle during follicular growth and atresia. Biology of Reproduction 21 75-87.

Clarke LJ, Irving-Rodgers HF, Dharmarajan AM \& Rodgers RR 2004 Theca Internat the other side of bovine follicular atresia. Biology of Reproduction 71 1071-1078. 
Crowe MA, Kelly P, Draincourt MA, Boland MP \& Roche JF 2001 Effects of follicle-stimulating hormone with and without luteinizing hormone on serum hormone concentrations, follicle growth, and intrafollicular estradiol and aromatase activity in gonadotropin-releasing hormone-immunised heifers. Biology of Reproduction 64 368-374.

Devine PJ, Payne CM, McCuskey MK \& Hoyer PB 2000 Ultrastructural evaluation of oocytes during atresia in rat ovarian follicles. Biology of Reproduction 63 1245-1252.

Dong J, Albertini DF, Nishimori K, Kumar TR, Lu N \& Matzuk MM 1996 Growth differentiation factor-9 is required during early ovarian folliculogenesis. Nature 383 531-535.

Driancourt M, Cahill L \& Bindon B 1985 Ovarian follicular populations and preovulatory enlargement in Booroola and Merino ewes. Journal of Reproduction and Fertility 73 93-107.

Driancourt MA, Reynaud K, Cortvrindt R \& Smitz J 2000 Roles of KIT and KIT Ligand in ovarian function. Reviews of Reproduction 5 143-152.

Dube IL, Wang P, Elvin J, Lyons KM, Celeste AJ \& Matzuk MM 1998 The bone morphogenetic protein 15 gene is $X$-linked and expressed in oocytes. Molecular Endocrinology 12 1809-1817.

Dugan KJ, Campbell BK, Skinner A, Armstrong DG \& Webb R 2004 Expression of bone morphogenetic protein-6 (BMP-6) in the bovine foetal ovary at different stages of gestation. Reproduction, Abstract Series 31 Abstract O46.

Eppig JI 2001 Oocyte control of ovarian follicular development and function in mammals. Reproduction 122 829-38.

Evans ACO, Ireland JLH, Winn ME, Lonergan P, Smith GW, Coussens PM \& Ireland IJ 2004 Identification of genes involved in apoptosis and dominant follicle development during follicular waves in cattle. Biology of Reproduction 70 1475-1484.

Fabre S, Pierre A, Pisselet C, Mulsant P, Lecerf F, Pohl J. Monget P \& Monniaux D 2003 The Booroola mutation in sheep is associated with an alteration of the bone morphogenetic protein receptor-1B functionality. Journal of Endocrinology 177435444.

Fatahei AN Van Den Hurk R, Colenbrander B, Daemen AJJM, Van Tol HTA, Monteiro RM, Roelen BAJ \& Bevers MM 2005 Expression of bone morphogenetic protein-2 (BMP-2), BMP-4 and BMP receptors but absence of effects of BMP-2 and BMP-4 during IVM on bovine oocyte nuclear maturation and subsequent embryo development. Theriogenology 63 $872-889$

Fayad T, Lévesque V, Sirois J, Silversides DW \& Lussier JG 2004 Gene expression profiling of differentially expressed genes in granulosa cells of bovine dominant follicles using suppression subtractive hybridization. Biology of Reproduction 70 523-533.

Fenwick MA \& Hurst PR 2002 Immunohistochemical localization of active caspase- 3 in the mouse ovary: growth and atresia of small follicles. Reproduction 124 659-665.
Fortune JE, Cushman RA, Wahl CM \& Kito WS 2000 The primordial to primary follicle transition. Molecular and Cellular Endocrinology 163 53-60.

Fouladi-Nashta AA, Dugan KJ \& Webb R 2005 Immunohistochemical localisation of BMP receptors in bovine foetal ovaries. Reproduction, Abstract Series 32 Abstract 72.

Garverick HA, Baxter G, Gong I, Armstrong DG, Campbell BK, Gutierrez CG \& Webb R 2002 Regulation of expression of ovarian mRNA encoding steroidogenic enzymes and gonadotrophin receptors by $\mathrm{FSH}$ and $\mathrm{GH}$ in hypogonadotrophic cattle. Reproduction 123 651-661.

Ginther OJ, Beg MA, Bergfelt DR \& Kot K 2002 Activin $A$, estradiol and free insulin-like growth factor $I$ in follicular fluid preceding the experimental assumption of follicle dominance in cattle. Biology of Reproduction 67 14-19.

Glister C, Groome NP \& Knight PG 2003 Oocyte-mediated suppression of follicle-stimulating hormone and insulin-like growth factor induced secretion of steroids and inhibin-related proteins by bovine granulosa cells in vitro: possible role of transforming growth factor $\alpha$. Biology of Reproduction 68 758-765.

Glister C, Kemp CF \& Knight PG 2004 Bone morphogenetic protein (BMP) ligands and receptors in bovine ovarian follicle cells: actions of $B M P-4,-6$ and 7 on granulosa cells and differential modulation of Smad-1 phosphorylation by follistatin. Reproduction 127 239-254.

Glister C, Richards SL \& Knight PG 2005 Bone morphogenetic proteins (BMP) $-4,-6$, and -7 potently suppress basal and luteinising hormone-induced androgen production by bovine theca interna cells in primary culture: could ovarian hyperandrogenic dysfunction be caused by a defect in thecal BMP signalling. Endocrinology 146 1883-1892.

Gong JG, Bramley TA \& Webb R 1991 The effect of recombinant bovine somatotropin on ovarian function in heifers: follicular populations and peripheral hormones. Biology of Reproduction 45 941-949.

Gong JG, Bramley TA \& Webb R 1993 The effect of recombinant bovine somatotrophin on ovarian follicular growth and development in heifers. Journal of Reproduction and Fertility 97 247-254.

Gong JG, Baxter G, Bramley TA \& Webb R 1997 Enhancement of ovarian follicle development in heifers by treatment with recombinant bovine somatotrophin: a dose response study. fournal of Reproduction and Fertility 110 91-97.

Gong JG, Armstrong DG, Baxter G, Hogg CO, Garnsworthy PC \& Webb R 2002. The effect of increased dietary intake on superovulatory response to $\mathrm{FSH}$ in heifers. Theriogenology 57 1591-1602.

Gonzalez-Anover P, Encinas T, Garcia-Garcia RM, Veiga-Lopez A, Cocero MJ, McNeilly AS \& Gonzalez-Bulnes A 2004 Ovarian response in sheep superovulated after pretreatment with growth hormone and GnRH antagonists is weakened by failures in oocyte maturation. Zygote 12 301-304.

Gonzalez-Bulnes A, Santiago-Moreno J, Garcia-Garcia 
RM, Souza CJ, Lopez-Sebastian A \& McNeilly AS 2004 Effect of GnRH antagonists treatment on gonadotrophin secretion, follicular development and inhibin A secretion in goats. Theriogenology 61977. 985.

Gougeon A 1996 Regulation of ovarian follicular development in primates: facts and hypotheses. Endocrine Reviews 17 121-155.

Gutierrez CG, Campbell BK \& Webb R 1997 Development of a long-term bovine granulosa cell culture system: induction and maintenance of estradiol production, response to follicle stimulating hormone and morphological characteristics. Biology of Reproduction 56 608-616.

Gutierrez CG, Ralph JH, Telfer EE, Wilmut I \& Webb R 2000 Growth and antrum formation of bovine antral follicles in long-term culture in vitro. Biology of Reproduction 62 1322-1328.

Hampton JH, Bader JF, Lamberson WR, Smith MF, Youngquist RS \& Garverick HA 2004 Gonadotrophin requirements for dominant follicle selection in GnRH agonist-treated cows. Reproduction 127 695703.

Hanrahan JP, Gregan SM, Mulsant P, Mullen M, Davis GH, Powell R \& Galloway SM 2004 Mutations in the genes for oocyte-derived growth factors GDF9 and BMP15 are associated with both increased ovulation rate and sterility in Cambridge and Belclare sheep (Ovis Aries). Biology of Reproduction 70 900909.

Hunter MG, Robinson RS, Mann GE \& Webb R 2004 Endocrine and paracrine control of follicular development and ovulation rate in farm species. Animal Reproduction Science 82-83 461-477.

Huntriss I, Gosden R, Hinkins M, Oliver B, Miller D, Rutherford AJ \& Picton HM 2002 Isolation, characterization and expression of the human Factor In the Germline alpha (FIGLA) gene in ovarian follicles and oocytes. Molecular Human Reproduction 8 $1087-1095$.

Ireland II \& Roche IF 1982 Development of antral follicles in cattle following prostaglandin-induced luteolysis: changes in serum hormones, steroids in follicular fluid and gonadotropin receptors. Endocrinology $1112077-2086$.

Jayawardana BC, Shimizu T, Nishimoto H, Kaneko E, Tetsuka M \& Miyamoto A 2006 Hormonal regulation of expression of growth differentiation factor-9 receptor type I and II in the bovine ovarian follicle. Reproduction 131 545-553.

Juengel $\mathrm{L}$, Hudson NL, Whiting L \& McNatty KP 2004 Effects of immunisation against bone morphogenetic protein 15 and growth differentiation factor 9 on ovulation rate, fertilization, and pregnancy in ewes, Biology of Reproduction 70 557-561.

Juengel JL, Reader KL, Bibby AH, Lun S, Ross I, Haydon LJ \& MCNatty KP 2006 The role of bone morphogenetic proteins 2, 4, 6 and 7 during ovarian follicular development in sheep: contrast to rat. Reproduction 131 501-513.

Kanitz W, Becker F, Schneider F, Kanitz E, Leiding C,
Nohner HP \& Pohland R 2002 Superovulation in cattle: practical aspects of gonadotropin treatment and insemination. Reproduction Nutrition Development 42 587-599.

Kash JC \& Menon KMJ 1999 Sequence-specific bind. ing of a hormonally regulated mRNA binding protein to cytidine-rich sequences in the lutropin receptor open reading frame. Biochemistry 3816889. 16897.

Kawate N \& Okuda K 1998 Coordinated expression of splice variants for luteinising hormone receptor messenger RNA during the development of bovine corpora lutea. Molecular Reproduction and Development 51 66-75.

Knight PG \& Glister C 2001 Potential local regulatory functions of inhibins, activins and follistatin in the ovary. Reproduction 121 503-512.

Knight PG \& Glister C 2006 TGF-B superfamily members and ovarian follicle development, Reproduction 132 191-206.

Kojima FN, Berfeld EGM, Wehrman ME, Cupp AS, Fike KE, Mariscal-Aguayo DV, Sanchez-Torres T, Garcia-Winder M, Clopton DT, Roberts AJ \& Kinder JE 2003. Frequency of hormone pulses in cattle influences duration of persistence of dominant ovarian follicles, follicular fluid concentration of steroids, and activity of insulin-like growth factor binding proteins. Animal Reproduction Science 77 187-211.

Kulick LJ, Kot K, Wiltbank MC \& Ginther OJ 1999 Follicular and hormonal dynamics during the first follicular wave in heifers. Theriogenology 52913 921.

Lin JG, Lerch TF, Cook RW, Jardetzky TS \& Woodruff TK 2006 The structural basis of TGF- $B$, bone morphogenetic protein, and activin ligand binding. Reproduction 132 179-190.

Loosfelt $H$, Misrahi $M$, Afger $M$, Salesse $R$, Thi MTVHL, Jolivet A, Guiochon-Mantel A, Sar S, Jallal B, Garnier J \& Milgrom E 1989 Cloning and sequencing of porcine LH-hCG receptor CDNA: variants lacking transmembrane domain. Science 245 525-528.

Lopez-Alonso C, Encinas T, Veiga-Lopez A, GarciaGarcia RM, Cocero MJ, Ros JM, McNeilly AS \& Gonzalez-Bulnes A 2005 Follicular growth, endocrine response and embryo yields in sheep superovulated with FSH after pretreatment with a single short-acting dose of $\mathrm{GnRH}$ antagonist. Theriogenology 64 1833-1843.

Lopez H, Sartori R \& Wiltbank MC 2005 Reproductive hormones and follicular growth during the development of one or multiple dominant follicles in cattle. Biology of Reproduction 72 788-795.

Lucy MC 2000 Regulation of ovarian follicular growth by somatotropins and insulin-like growth factors in cattle. Journal of Dairy Science 83 1635-1647.

Macklon NS \& Fauser BC 2005 Ovarian reserve. Seminars in Reproductive Medicine 23 248-56.

Macklon NS, Stouffer RL, Giudice LC \& Fauser BC 2006 The science behind 25 years of ovarian stimulation for in vitro fertilization. Endocrine Reviews 27 170-207. 
Marsters P, Kendall NR \& Campbell BK 2003 Temporal relationships between FSH receptor, type 1 insulin-like growth factor receptor, and aromatase expression during $\mathrm{FSH}$-induced differentiation of bovine granulosa cells maintained in serum-free culture. Molecular and Cellular Endocrinology 203 117-127.

Marsters P, Kendall NR \& Campbell BK 2007 Expression of luteinising hormone receptor mRNA splice variants in bovine ovarian somatic cells induced to differentiate in vitro. Journal of Endocrinology (in press)

Matikainen T, Perez GI, Zheng TS, Kluzak TR, Rueda BR, Flavell RA \& Tilly JL 2001 Caspase-3 gene knockout defines cell lineage specificity for programmed cell death signaling in the ovary. Endocrinology 142 2468-2480.

Mazerbourg S, Zapf J, Bar RS, Brigstock DR \& Monget P 2000 Insulin-like growth factor (IGF)-binding protein-4 proteolytic degradation in bovine, equine, and porcine preovulatory follicles: regulation by IGFs and heparin-binding domain-containing peptides, Biology of Reproduction 63 390-400.

McCaffery FH, Leask R, Riley SC \& Telfer EE 2000 Culture of bovine pre-antral follicles in a serum-free system: markers for assessment of growth and development. Biology of Reproduction 63 267-273.

McNatty K, Henderson KM, Lun S, Heath DA, Ball K, Hudson NL, Fannin J, Gibb M, Kieboom IE \& Smith P 1985 Ovarian activity in Booroola $\times$ Romney ewes which have a major gene influencing their ovulation rate. Journal of Reproduction and Fertility 73 109-120.

McNatty K, Hudson N, Henderson K, Gibb M, Morrison L, Ball K \& Smith P 1987 Differences in gonadotrophin concentrations and pituitary responsiveness to GnRH between Booroola ewes which were homozygous (FF), heterozygous $(\mathrm{F}+)$ and non-carriers $(++)$ of a major gene influencing their ovulation rate. fournal of Reproduction and Fertility $\mathbf{8 0} 577$. 588.

McNatty K, Kieboom L, McDiarmid J, Heath D \& Lun S 1986 Adenosine cyclic 3',5' monophosphate and steroid production by small ovarian follicles from Booroola ewes with and without a fecundity gene. Journal of Reproduction and Fertility 76 471-480.

McNatty KP, Reader K, Smith P, Heath DA \& Juengel IL 2006 Control of ovarian follicular development in the gonadotrophin-dependent phase: a 2006 perspective. Reproduction Supplement (this issue, in press).

Mee MO, Stevenson IS, Alexander BM \& Sasser RG 1991 Administration of $\mathrm{GnRH}$ at estrus influences pregnancy rates, serum concentrations of $\mathrm{IH}, \mathrm{FSH}$, estradiol-17 beta, pregnancy-specific protein B, and progesterone, proportion of luteal cell types, and in vitro production of progesterone in dairy cows. Journal of Dairy Science 74 1573-1581,

Mee MO, Stevenson JS \& Minton JE 1993 First postpartum luteal function in dairy cows after ovulation induced by progestogen and gonadotropin-releas- ing hormone. Journal of Animal Science 71185 . 198.

Mihm M, Austin EJ, Good TEM, Ireland JtH, Knight PG, Roche JF \& Ireland JJ 2000 Identification of potential intrafollicular factors involved in selection of dominant follicles in heifers. Biology of Reproduction 63 811-819.

Mihm M, Baker PJ, Ireland JL, Smith GW, Coussens PM, Evans AC \& Ireland JJ 2006 Molecular evidence that growth of dominant follicles involves a reduction in follicle-stimulating hormone dependence and an increase in luteinizing hormone dependence in cattle. Biology of Reproduction 741051 1059.

Monget P, Pisselet C \& Monniaux D 1998 Expression of insulin-like growth factor binding protein-5 by ovine granulosa cells is regulated by cell density and programmed cell death in vitro. Journal of Cell Physiology 177 13-25.

Monget P, Mazerbourg S, Delpuech T, Maurel MC, Maniere S, Zapf J, Lalmanach G, Oxvig C \& Overgaard MT 2003. Pregancy-associated plasma protein $A$ is involved in insulin-like growth factor binding protein-2 (IGFBP-2) proteolytic degradation in bovine and porcine preovulatory follicles: identification of cleavage site and characterization of IGFBP-2 degradation. Biology of Reproduction $6877-86$.

Nicholas B, Scougall RK, Armstrong DG \& Webb R 2002 Changes in insulin-like growth factor binding protein (IGFBP) isoforms during bovine follicular development. Reproduction 124 439-446.

Nicholas B, Alberio R, Fouladi-Nashta AA \& Webb R 2005 Relationship between low-molecular-weight insulin-like growth factor-binding proteins, caspase3 activity, and oocyte quality. Biology of Reproduction 72 796-804.

Peng XR, Hsueh AJW, LaPolt PS, Bjersing L \& Ny T 1991 Localisation of luteinising hormone receptor messenger ribonucleic acid expression in ovarian cell types during follicle development and ovulation. Endocrinology 129 3200-3207.

Perry GA, Smith MF, Lucy MC, Green JA, Parks TE, MacNeil MD, Roberts AJ \& Geary TW 2005 Relationship between follicle size at insemination and pregnancy success. Proceedings of the National Academy of Science 102 5268-5273

Picton HM, Danfour MA, Harris SE, Chambers EL \& Huntriss J 2003 Growth and maturation of oocytes in vitro. Reproduction Supplement 61 445-462.

Price CA \& Webb R 1989 Ovarian response to hCG treatment during the oestrous cycle in heifers. Journal of Reproduction and Fertility 86 303-308.

Quirk SM, Harman RM \& Cowan RG 2000 Regulation of Fas antigen (Fas, CD95)-mediated apoptosis of bovine granulosa cells by serum and growth factors. Biology of Reproduction 63 1278-1284.

Reinholz MM, Zschunke MA \& Roche PC 2000 Loss of alternately spliced messenger RNA of the luteinising hormone receptor and stability of the follicle-stimulating hormone receptor messenger RNA in granu- 
losa cell tumours of the human ovary. Cynaecologic Oncology 79 264-271.

Reynaud K, Cortvrindt R, Smitz J, Bernex F, Panthier JJ \& Driancourt MA 2001 Alterations in ovarian function of mice with reduced amounts of KIT receptor. Reproduction 121 229-237.

Reynaud K, Cortvrindt R, Smitz I \& Driancourt MA 2000 Effects of Kit Ligand and anti-Kit antibody on growth of cultured mouse preantral follicles. Molecular Reproduction Development 56 483-494.

Robert C, Gagne D, Lussier JG, Bousquet D, Barnes FL \& Sirard MA 2003 Presence of LH receptor mRNA in granulosa cells as a potential marker of oocyte developmental competence and characterisation of the bovine splicing isoforms. Reproduction 125437 446.

Saha S, Shimizu M, Geshi M \& Izaike Y 2000 In vitro culture of bovine pre-antral follicles. Animal Reproduction Science 63 27-39.

Siontouris 12004 Oocyte-somatic cell interactions during oogenesis and folliculogenesis in monovular species. PhD Thesis, University Of Nottingham

Shimasaki S, Moore RK, Erickson GF \& Otsuka F 2003 The role of bone morphogenetic proteins in ovarian function. Reproduction Suppement 61 323-37.

Shimasaki S, Moore RK, Otsuka F \& Erickson GF 2004 The bone morphogenetic protein system in mammalian reproduction. Endocrine Reviews 25 72-101.

Simpson RB, Chase Jr CC, Spicer LJ, Vernan RK, Hammond AL \& Rae DO 1994 Effects of exogenous insulin on plasma and follicular insulin like growth factor I, insulin like growth factor binding activity, follicular oestradiol and progesterone and follicular growth in superovulated Angus and Brahman cows. Journal of Reproduction and Fertility 102 483-492.

Smith MF, Gutierrez CG, Ricke WA, Armstrong DG \& Webb R 2005 Production of matrix metalloproteinases by cultured bovine theca and granulosa cells. Reproduction 129 75-87.

Smitz JE \& Cortvindt RG 2002 The earliest stages of folliculogenesis in vitro. Reproduction 123 185-202.

Souza CJH, Campbell BK \& Baird DT 1997. Follicular dynamics and ovarian steroid secretion in sheep during the follicular and early luteal phases of the estrous cycle. Biology of Reproduction 56 483-488.

Souza CJH, Campbell BK, McNeilly AS \& Baird DT 2002. Effect of bone morphogenetic protein 2 (BMP2) on oestradiol and inhibin A production by sheep granulosa cells, and localization of BMP receptors in the ovary by immunohistochemistry. Reproduction 123 363-369.

Soyal SM, Amleh A \& Dean J 2000 FiGalpha, a germ cell-specific transcription factor required for ovarian follicle formation. Development 127 4645-4654.

Spicer LJ, Voge JL \& Allen DT 2004 Insulin-like growth factor-II stimulates steroidogenesis in cultured bovine thecal cells. Molecular and Cellular Endocrinology 227 1-7.

Thomas FH, Leask R, Srsen V, Riley SC, Spears N \& Telfer EE 2001 Effect of ascorbic acid on health and morphology of bovine pre-antral follicles during long- term cultures. Reproduction 122 487-495.

Tilly JL, Kowalski KI, Johnson AL \& Hsueh AJ 1991 Involvement of apoptosis in ovarian follicular atresia and postovulatory regression. Endocrinology 129 2799-2801.

Tilly JL, Kowalski KI, Schomberg DW \& Hsueh AJ 1992 Apoptosis in atretic ovarian follicles is associated with selective decreases in messenger ribonucleic acid transcripts for gonadotropin receptors and cytochrome P450 aromatase. Endocrinology 131 1670-1676.

Turnbull K, Braden A \& Mattner P 1977 The pattern of follicular growth and atresia in the ovine ovary. Australian Journal of Biological Sciences 30 229-241.

Twagiramungu H, Guilbault LA, Proulx JG \& Dufour JJ 1995 Buserelin alters the development of the corpora lutea in cyclic and early postpartum cows. Journal of Animal Science 73 805-811.

Visser JA, de Jong FH, Laven JS \& Themmen AP 2006 Anti-Mullerian hormone: a new marker for ovarian function. Reproduction 131 1-9.

Walters KA, Binnie JP, Campbell BK, Armstrong DG \& Telfer EE 2006 The effects of IGF-I on bovine follicle development and IGFBP-2 expression are dose and stage dependent Reproduction 131 515-523.

Webb R, Gong JG, Law AS \& Rusbridge SM 1992 Control of ovarian function in cattle. Journal of Reproduction and Fertility Supplement $\mathbf{4 5}$ 141-156.

Webb R, Campbell BK, Garverick HA, Gong JG, Gutierrez CG \& Armstrong DG 1999 Molecular mechanisms regulating follicular recruitment and selection. Journal of Reproduction and Fertility Supplement $\mathbf{5 4}$ 33-48.

Webb R \& England BG 1982 Relationship between LH receptor concentrations in thecal and granulosa cells and in-vivo and in-vitro steroid secretion by ovine follicles during the pre-ovulatory period. Journal of Reproduction and Fertility 66 169-180.

Webb R, Nicholas B, Gong JG, Campbell BK, Gutierrez CG, Gaverick HA \& Armstrong DG 2003 Mechanism regulating follicular development and selection of the dominant follicle. Reproduction Supplement 61 71-90.

Webb R, Garnsworthy PC, Gong J-G \& Armstrong DG 2004 Control of follicular growth: local interactions and nutritional influences. Journal of Animal Science 82 E63-E74.

Xu Z, Garverick HA, Smith GW, Smith MF, Hamilton SA \& Youngquist RS 1995 Expression of follicle stimulating hormone and luteinising hormone receptor messenger ribonucleic acids in bovine follicles during the first follicular wave. Biology of Reproduction 53 951-957.

Yong PY, Baird DT, Thong KJ, McNeilly AS \& Anderson RA 2003 Prospective analysis of the relationships between the ovarian follicle cohort and basal $\mathrm{FSH}$ concentration, the inhibin response to exog. enous FSH and ovarian follicle number at different stages of the normal menstrual cycle and after pituitary down-regulation. Human Reproduction 1835 . 44. 
Yuan W, Bao B, Garverick HA, Youngquist RS \& Lucy MC 1998 Follicular dominance in cattle is associated with divergent patterns of ovarian gene expression for insulin-like growth factor (IGF) -I, IGF-II and IGF binding protein-2 in dominant and subordinate follicles. Domestic Animal Endocrinology 15 55-63.

Zeuner A, Muller K, Reguszynski K \& Jewgenow K 2003 Apoptosis within bovine follicular cells and its effect on oocyte development during in vitro maturation. Theriogenology 59 1421-1433. 